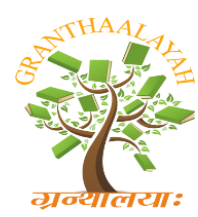

INTERNATIONAL JOURNAL OF RESEARCH GRANTHAALAYAH

A knowledge Repository

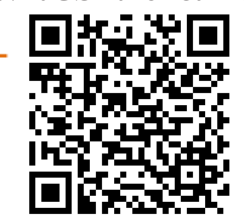

Social

\title{
ATTITUDE OF TEACHER EDUCATORS TOWARDS ICT
}

\author{
P.Ganesan ${ }^{1}$, Dr. R.Krishnakumar ${ }^{2}$ \\ ${ }^{1}$ Research Scholar, Bharathiar University, Coimbatore \& 1Asst. Prof. in Social Science, CMS \\ College of Education, Ganapathy ,Coimbatore, INDIA \\ ${ }^{2}$ Professor of Education, Annamalai University, Annamalai Nagar, INDIA
}

\begin{abstract}
Realizing the attitude of teacher educators towards ICT is essential to incorporate its betterments in teacher preparation programmes. This study examined the difference between teacher educators' attitude towards ICT and their level of attitude; whether it is favourable or unfavourable? The participants were the teacher educators of Colleges of Education in Coimbatore, South India. Cluster Sampling was adopted. Results indicated significant difference in their attitude with respect to their locality of home. Majority of teacher educators have favourable attitude.
\end{abstract}

Keywords:

ICT, teacher educators, teacher preparation programmes, Education.

Cite This Article: P.Ganesan, and Dr. R.Krishnakumar, "ATTITUDE OF TEACHER EDUCATORS TOWARDS ICT" International Journal of Research - Granthaalayah, Vol. 4, No. 5: SE (2016): 7-11.

\section{INTRODUCTION}

The surveys of recent years which have been accomplished on education system say that Information and Communication Technology (ICT) facilitates the enrichment of learning outcomes.

Teacher education is a vital programme for the betterments of society. The learning outcomes of teacher education programmes should not have pitfalls and blockades. The enhancement of learning outcomes should change the society in all endeavours. Teacher is considered to be the architect of the nation. In other words, the prospect of the nation lies in the hands of teacher. This illustrates the significance of teacher. Various education commissions and number of expert committee suggests and advocates that the incorporation of ICT in each and every aspect of teacher preparation programmes definitely will enhance the quality of future teachers. They are envisaging that ICT will fetch about numerous benefits to the learner and the teacher. These include partaking of resources and learning environments as well as the promotion of concerted learning and a universal move towards greater learner autonomy. In order to produce quality 
teachers the teacher educators should be trained in ICT. Inferring the deficiency of the lack of ICT skilled human resources, the regulatory bodies like NCTE, NCERT, SERT, ISTE etc., as a capacity building exercise conducted ICT literacy camps for teacher educators throughout India. The interest, attention and attitude of the teacher educators are most essential key parts to inculcate the sound knowledge of ICT among their student teachers.

\section{NEED FOR THE STUDY}

It is evident that a teacher who has the sound knowledge of new pedagogic approach will be pointed in any context of education. The teacher educators must understand that their students are the future teachers and they must begin to reappraise the methods by which they meet pupils' learning needs and match curricula to the requirements of human thought. Today children are living in digital era. They have so many e-learning platforms in their hands. They are using laptops, iPods, smart phones and computers. They have $3 \mathrm{G}$ and $4 \mathrm{G}$ networks to catch the internet. The traditional teaching with chalk board will bring the desirable change in some extend only. With the help of multimedia the advancement of technology initiate children to get multiple intelligence. In order to satisfy the needs of learners the future teachers should learn the emerging pedagogy which is ICT enabled. For that the teacher educator should inculcate the knowledge of active learning, collaborative learning, integrative learning, creative learning and evaluative learning among his student teachers which are ICT enabled for better learning outcomes. Hence the need arises to study the attitude of teacher educators towards ICT with initiative objectives.

\section{OBJECTIVES OF THE STUDY}

1) To study the attitude of teacher educators towards ICT.

2) To study the attitude of teacher educators towards ICT in relation to their gender.

3) To study the attitude of teacher educators towards ICT in relation to their locality of home.

\section{HYPOTHESES OF THE STUDY}

1) Teacher educators do not have favourable attitude towards ICT.

2) There is no significant difference between male and female teacher educators in their attitude towards ICT.

3) There is no significant difference between rural and urban teacher educators in their attitude towards ICT.

\section{METHODOLOGY}

The Descriptive Survey Method was adopted to investigate the aim of the present study viz., attitude of teacher educators towards ICT. 


\section{SAMPLE}

Sample consisted of 12 male and 18 female teacher educators selected from the esteemed teacher education colleges in Coimbatore, South India. Cluster sampling method was adopted.

\section{TOOL USED}

In the present study, Attitude scale on ICT was used to collect the required information. The tool was standardised by the investigator. The reliability of the scale was determined through KuderRichardson formula is 0.82 .

\section{STATISTICAL TECHNIQUES USED}

In the present study, the following statistical techniques were used: Mean, Standard deviation and t-test.

\section{ANALYSIS AND INTERPRETATION OF DATA}

Hypothesis 1: Teacher educators do not have favourable attitude towards ICT.

The percentage analysis of raw scores of teacher educators was done to verify the hypothesis.

Table 1: Shows the Attitude level based on the Percentage Analysis

\begin{tabular}{|l|l|l|l|l|}
\hline S.No & Percentage & No of Teacher Educators & Level & Attitude \\
\hline 1 & 10 & 3 & Below Average & Unfavourable \\
\hline 2 & 30 & 9 & Average & Moderate \\
\hline 3 & 60 & 18 & Above Average & Favourable \\
\hline
\end{tabular}

From the above table it is observed that $10 \%$ of teacher educators have unfavourable attitude, 30 $\%$ of teacher educators have moderate attitude and $60 \%$ have favourable attitude towards ICT. The analysis reveals that most of the teachers have favourable attitude and shows the hypothesis 'Teacher educators do not have favourable attitude towards ICT' is rejected.

Hypothesis 2: There is no significant difference between male and female teacher educators in their attitude towards ICT.

Table 2: N, Mean, S.D and t- Value: Gender

\begin{tabular}{|l|l|l|l|l|l|}
\hline S.No & Variable & N & Mean & SD & t-Value \\
\hline 1 & Female & 18 & 148.78 & 28.65 & \multirow{2}{*}{14} \\
\cline { 1 - 5 } & Male & 12 & 160.92 & 27.85 & \\
\hline
\end{tabular}

The calculated t-value (1.14) is not significant at 0.05 level which shows that there exists no significant difference between male and female teacher educators in their attitude towards ICT. Hence the hypothesis 'There is no significant difference between male and female teacher educators in their attitude towards ICT' is accepted. 
Hypothesis 3: There is no significant difference between rural and urban teacher educators in their attitude towards ICT.

Table 2: N, Mean, S.D and t- Value: Locality of home

\begin{tabular}{|l|l|l|l|l|l|}
\hline S.No & Variable & N & Mean & SD & t-Value \\
\hline 1 & Rural & 11 & 129.18 & 28.36 & \multirow{2}{*}{4.69} \\
\cline { 1 - 4 } 2 & Urban & 19 & 167.79 & 16.87 & \\
\hline
\end{tabular}

The above table shows highly significant difference between rural and urban teacher educators at 0.01 level. The mean scores for rural and urban teacher educators are 129.18 and 167.79 respectively. The ' $t$ ' value is 4.69 , which is high. So the hypothesis No.3 (There is no significant difference between rural and urban teacher educators in their attitude towards ICT) stands rejected.

\section{FINDINGS}

1) Majority of Teacher Educators in the sample have favourable attitude towards ICT. $10 \%$ of teacher educators have unfavourable attitude, $30 \%$ of teacher educators have moderate attitude and $60 \%$ have favourable attitude towards ICT.

2) There is no significant difference between male and female teacher educators in their attitude towards ICT.

3) There is significant difference between rural and urban teacher educators in their attitude towards ICT.

\section{CONCLUSION}

The inference of present investigation has dragged the attention of experts towards the teacher educators of rural areas. The comparison of mean scores shows the huge difference. Special training programmes on ICT should be organised for them. The regulatory bodies should monitor the implantation of ICT in teacher education curriculum at all the levels. All universities should take initiation of ICT studios for innovative pedagogical perspectives.

\section{REFERENCES}

[1] Askar, P., \& Olkun, S. (2005). The use of ICT in schools based on PISA 2003 data. Eurasian Journal of Educational Research, 19, 15 - 34.

[2] Afshari, Mojgan. 2009. "Factors Affecting Teachers Use of ICT." International Journal of Instruction 2(1): 77-104.

[3] Anderson, J. (2010). ICT transforming education: A regional guide. Bangkok: UNESCO.

[4] Brosnan, T. (2001). Teaching Using ICT. University of London: Institute of Education.

[5] Chaudhary, S.S: Teachers' Attitude Towards School Television and Its Relationship to Mass Media Behaviour and Job Satisfaction. Unpublished doctoral dissertation, University of Delhi, New Delhi, (1990).

[6] Golden, S. A. R. (2011). Problems and Prospectus of Distance Learning, Bharathidhasan University, 343- 344. 
[7] Dupagne, M. and Krendl, K.A. (1992). "Teachers' Attitudes Toward Computers: A Review of the Literature”, Journal of Research on Computing in Education, 24, pp. 420429.

[8] Golden, S. A. R. (2011). Quality Enhancement In Distance Education For Life Long Learning.

[9] Kishan, Ramnath N. (2007). Global Trends in Teacher Education, A. P. H. Publishing Corporation, New Delhi.

[10] Kok, A. (2007). ICT Integration into Classrooms: Unpublished literature review.

[11] MHRD, GOI. 2008. Towards a National Policy on ICT in School Education in India.

[12] Nachimuthu,K \& Vijaykumari,G: Modern ICT Trends in Teaching Technology, Edu Tracks, 6(6), 18-20, Feb., 2007.

[13] Pradeep, T.K.: ICT Among B.Ed. Colleges. Professional Competence in Teaching published by Rakhi Prakashan, sanjay Place, Agra. ISBN: 978-93-80375-02-1.

[14] Sadik, A. (2006). Factors Influencing Teachers' Attitudes toward Personal Use and School Use of Computers: New Evidence from a Developing Nation. Evaluation Review, 30(1), 86-113.

[15] Sudhakar, S.B.: Technological Advances and Role of ICT in Teacher Training and Higher Education. University News, 45(26), 12, June 25-July 1, 2007.

[16] Mumtaz, Shazia. 2000. "Factors Affecting Teachers" Use of Information and Communications Technology: A Review of the Literature." Journal of Information Technology for Teacher Education 9(3): 319-342.

[17] Yousef, A. B. and Dahamini, M. (2008). The Economics of E-Learning: The Impact of ICT on Student Performance in Higher Education: Direct Effects, Indirect Effects and Organizational Change. 